Editorial

\title{
Sustainability Issues in Textile and Apparel Supply Chains
}

\author{
Bin Shen ${ }^{1}$, Qingying $\mathrm{Li}^{1, *}$, Ciwei Dong ${ }^{2}$ and Patsy Perry ${ }^{3}$ \\ 1 Glorious Sun School of Business and Management, Donghua University, Shanghai 200051, China; \\ binshen@dhu.edu.cn \\ 2 School of Business Administration, Zhongnan University of Economics and Law, Wuhan 430073, China; \\ dongciwei@zuel.edu.cn \\ 3 School of Materials, The University of Manchester, Manchester M13 9PL, UK; patsy.perry@manchester.ac.uk \\ * Correspondence: liqingying@dhu.edu.cn
}

Received: 1 September 2017; Accepted: 5 September 2017; Published: 7 September 2017

\begin{abstract}
Incorporating sustainability into the supply chain is becoming a key priority for many textile and apparel companies. For example, H\&M, Patagonia, and The North Face have incorporated various approaches to enhance their levels of sustainable supply chain management. Typical approaches include sustainable product strategy, sustainable investment, sustainable performance evaluation, corporate social responsibility, and environmental management system adoption, which contribute to the development of sustainable supply chain management in the textile and apparel industry. In this paper, we introduce the fifteen articles published in this special issue, and summarize the key findings and future research directions in the area of textile and apparel sustainable supply chain management.
\end{abstract}

Keywords: textile and apparel industry; sustainable supply chain management; sustainable fashion; sustainability

\section{Introduction}

As one of the world's most polluting industries [1], sustainability issues in the textile and apparel industry have received great attention [2]. With geographically long and complex global production networks, as well as the dual pressure for cost and lead time, implementing sustainability in textile and apparel supply chains is challenging $[1,3,4]$. The process of turning raw materials into finished garments has significant negative environmental and social implications, including air and water pollution and exploitation of human resources, especially where production is outsourced to lower labor cost countries. The triple bottom line approach suggests that companies should consider social and environmental performance, not only financial performance, in their business operations. Furthermore, with increasing awareness of sustainability, there is evidence that some consumers are willing to pay more for sustainable textile and apparel products [5]. To meet stakeholders' increasing expectations and reduce the risk of negative social and environmental externalities, apparel firms across all market levels, such as fast fashion brand H\&M, outdoor wear brand Patagonia, and luxury brand Louis Vuitton, have implemented various approaches to enhance the level of sustainability in their supply chain management [6-8]. Being more sustainable is now key to developing the textile and apparel supply chain, and a number of issues and innovations relating to this goal have been examined in academic literature so far, including product returns, low carbon supply chain, corporate social responsibility, sustainable design operations, and sustainable competition $[3,4,8-19]$. However, there is still a lack of further and intensive investigation of many other current issues relating to sustainable supply chain management in today's global textiles and apparel industry. 


\section{Sustainability Issues in Textile and Apparel Supply Chains}

In this special issue, Köksal et al. [20] and Yang et al. [21] conducted comprehensive literature reviews to better understand the problems of sustainability issues, in addition to summarizing the relevant literature on sustainable textile and apparel supply chains. In the literature review of social issues in textile and apparel supply chain by Köksal et al. [20], the authors proposed a comprehensive map of the social dimension of sustainability. They argued that textile and apparel companies need to collaborate with suppliers to reduce social risks.

In their systematic review of sustainable retailing in the fashion industry, Yang et al. [21] found that the most prominent areas of literature include disposable fashion, fast fashion, slow fashion, green branding, and eco-labeling. They identified research opportunities in retailing of second-hand fashion, reverse logistics in fashion retailing, and emerging retailing opportunities in e-commerce.

Developing a sustainable textile and apparel supply chain should follow the theory of the triple bottom line, which refers to the three pillars of Profit (economic), People (social), and Planet (environment). Guo et al. [22] examined the green supplier evaluation and selection approach in global apparel manufacturing. They first developed a methodological framework for the evaluation and selection of green suppliers based on the triple bottom line, and then proposed a fuzzy multi-criteria decision-making model for evaluating and selecting the best material suppliers. A sensitivity analysis was conducted to verify the effectiveness of the proposed supplier evaluation and selection model.

Kim and Kim [23] analyzed data from news articles and firms' annual reports relating to sustainability in the textile and apparel industry. They used Leximancer, a computer-based content analysis approach, and DICTION, a dictionary-based text mining program, for textual and rhetorical analysis. They found the contents of their sources to be consistent with the concept of the triple bottom line and also identified cross-cultural differences between North American and European sources, whereby North American firms show relatively high commonality, while European firms show relatively high realism.

Lee and Ha-Brookshire [24] examined several factors within fashion retail businesses, including the ethical climate, employees' attitudes toward their jobs, and employees' turnover intention, that affect organizational performance in triple bottom line terms. Data from 278 U.S. fashion retail employees were analyzed using structural equation modeling. They found that an ethical climate can enhance employees' job attitude as well as all three dimensions of the triple bottom line. The results imply that organizational sustainability performance can be improved not only by employees' attitudes toward their jobs but also by the presence of an ethical working environment.

Developing a closed-loop supply chain is an important indicator of sustainability. Norum [25] investigated the consumer apparel disposal process using a qualitative approach, conducting semi-structured in-depth interviews with 24 female U.S. consumers. The author identified several important themes: the use of both "compensatory" and "non-compensatory" choice heuristics in decision-making, a "usable life" and the "personal nature" of garments as barriers to non-trash disposal options, and the need to "create awareness" and "provide assurance" to encourage alternative disposal modes.

Yang and Dong [26] investigated sustainable apparel product strategy where products are partially produced using recycled materials. They considered two types of consumers: environmentally conscious and regular consumers. Their analytical results indicated that if consumers value sustainable products more, the firm will increase its sustainability level and gain a higher profit. Moreover, if converting regular consumers to be environmentally conscious is not too costly, firms should provide sufficient sustainability information for consumers, in order to encourage all consumers to be environmentally conscious.

$\mathrm{Li}$ and $\mathrm{Wu}$ [27] examined how environmental management system (EMS) adoption affects changes of firms' performance in profitability, sales, and operational efficiency. Taking an event study approach, they analyzed 22 events of EMS adoption in China and found that EMS adoption decreased firms' 
profitability, sales, and inventory productivity. Losses in operational efficiency and flexibility were found to be due to the requirements of the EMS adoption.

Le and Wang [28] used grey prediction to forecast productivity for the 20 largest enterprises over six years (2016-2021) based on actual indicators and then adopted a window analysis to detect performance trend over 12 years (2010-2021) from a large number of inputs and outputs. They predicted that textile companies will be more stable in terms of supplying materials for the entire industry.

Supply chain leadership significantly influences the performance of sustainability. Niu et al. [29] developed an analytical model to examine the impact of suppliers' attitudes to loss on the fashion supply chain's sustainability and profitability. They evaluated wholesale prices and buyback contracts under various power structures, and found that buyback contracts can reduce the sustainability of the supply chain. Meanwhile, the sustainability index increases in the buyback price in the supplier-as-leader scenario, but decreases in the retailer-as-leader scenario. When the supplier acts as leader and the buyback price is lower than a certain threshold, the sustainability level improves.

Shi et al. [30] evaluated economic and environmental performance in the fashion supply chain from a power perspective. Their analytical results implied that the follower with less supply chain power has incentive to make more sustainable efforts and achieve a higher profit. In most scenarios, the optimal amount of sustainable investment is greater in the apparel manufacturer case than in the retailer case.

Incorporating sustainability into the textile and apparel supply chain is a value-added process. LoMonaco-Benzing and Ha-Brookshire [31] examined the personal and corporate moral values in the textile and apparel supply chain through semi-structured interviews. Three gaps were identified: the nature of the value gap, the frustration due to the value gap, and strategies to manage the value gap.

Yang et al. [32] evaluated the value creation mechanism based on a case study of Stella McCartney and parent company Kering. They developed a novel model for sustainable value creation, thus extending knowledge of value co-creation from co-creation with customers to co-creation with multiple stakeholders. Sustainable value co-creation mechanisms including the building blocks and specific practices are systematically and empirically identified.

Oelze [33] studied the existence of consensuses in the perception of barriers and enablers of sustainable supply chain implementation in the textile industry. The author conducted a case study with 23 interviews across 10 textile companies and showed that collaboration can enable sustainable policy implementation and reduce barriers. Furthermore, external pressure can support proactive changes and supply chain visibility.

Finally, Chen et al. [34] examined garment workers' concerns, satisfaction levels, and attitudes towards decent work in the Chinese garment manufacturing industry, collecting data from both blue-collar and white-collar workers. Results indicate that age, education level, and service length significantly influence workers' attitudes towards decent work. Their study provided insights for the development of social responsibility in the Chinese garment manufacturing industry.

\section{Concluding Remarks}

This special issue advances the theories and practical understanding of developing sustainability in textile and apparel supply chains. Table 1 below presents the core issues and the proposed future research directions in the featured articles in this special issue. 
Table 1. Core topics and future research directions of the papers featured in this special issue.

\begin{tabular}{|c|c|c|}
\hline Paper & Core Topics & Future Research Directions \\
\hline Köksal et al. [20] & Sustainable supply chain management; social sustainability & - Environmental issues, such as the extension to environmental risk management \\
\hline Yang et al. [21] & Sustainable value; value co-creation; luxury sustainability & $\begin{array}{l}\text { - Use quantitative approaches to examine value creation } \\
\text { Develop a mechanism for sustainable value co-creation adapted from this one in response to the } \\
\text { characteristics of the fast fashion industry }\end{array}$ \\
\hline Guo et al. [22] & Fuzzy axiomatic design; evaluation criteria; triple bottom line & - Compare the performance of the proposed framework with other multi-criteria decision-making methods \\
\hline Kim and Kim [23] & Triple bottom line; text mining & - A macroscopic image of sustainability and supply chain management \\
\hline Lee and Ha-Brookshire [24] & Organizational sustainability performance; ethical climate; retailing & $\begin{array}{l}\text { - Cultural influences on outcomes of the triple bottom line of organizational performance } \\
\text { - } \quad \text { Managers' or other higher-level positions' perception of perceived organizational sustainability performance }\end{array}$ \\
\hline Norum [25] & Disposal; landfill and trash; post-consumer waste & - Test new conceptual models of consumer apparel disposal process within the textile and apparel supply chain \\
\hline Yang and Dong [26] & Social responsibility; market segmentation; consumer behavior & $\begin{array}{l}\text { - Explore the firm's incentive to adopt sustainable product strategies } \\
\text { - Consider non-economic aspects of strategy implementation i.e., branding, reputation, innovation }\end{array}$ \\
\hline $\mathrm{Li}$ and $\mathrm{Wu}[27]$ & Social sustainability performance & $\begin{array}{l}\text { - Medium- and long-term abnormal performance after environmental management system (EMS) adoption } \\
\text { - } \quad \text { Effects of regulation changes and public concern about environmental problems on abnormal performance }\end{array}$ \\
\hline Le and Wang [28] & Performance evaluation; sustainability performance; Vietnam & $\begin{array}{l}\text { - } \quad \text { More input and output variables in the proposed model } \\
\text { - } \quad \text { Different Data Envelopment Analysis (DEA) models to evaluate the performance of different industries }\end{array}$ \\
\hline Niu et al. [29] & Sustainability; power structure; attitude to loss & $\begin{array}{l}\text { - } \quad \text { Explore the impact of a positive salvage value } \\
\text { - } \quad \text { Consider delay in payments, imperfect production, probabilistic deterioration, and setup cost }\end{array}$ \\
\hline Shi et al. [30] & Sustainable investment; power structure; environmental tax & $\begin{array}{l}\text { - Investigate stochastic demand models } \\
\text { - } \quad \text { Study supply chain coordination with different contracts } \\
\text { sustore multi-retailer and/or multi-manufacturer structures and explore how the spillover effect influences }\end{array}$ \\
\hline $\begin{array}{l}\text { LoMonaco-Benzing and } \\
\text { Ha-Brookshire [31] }\end{array}$ & $\begin{array}{l}\text { Corporate sustainability; moral values; employee and consumer } \\
\text { identities }\end{array}$ & - Expand the research focus to non-industry professionals \\
\hline Yang et al. [32] & Sustainable retailing; developing country & - Investigate the negative effects of sustainable retailing on the fashion industry \\
\hline Oelze [33] & Sustainable supply chain management; responsible procurement & $\begin{array}{l}\text { - Conduct a cross-cultural comparison of the sample } \\
\text { - Expand the sample to furtherinstitutional contexts }\end{array}$ \\
\hline Chen et al. [34] & Decent work; blue-collar workers; white-collar workers; China & - Explore the connection between decent work and employee productivity, recruitment, and retention \\
\hline
\end{tabular}


Acknowledgments: We sincerely thank the Editor-in-Chief Marc A. Rosen and the managing editor Guoshui Liu for their kind support in the development and completion of this meaningful special issue. We are also indebted to all reviewers and authors for their hard work. Bin Shen's research is partially supported by the National Science Foundation of China (71401029), and Chenguang Program (15CG34), Qingying Li's research is partially supported by the National Science Foundation of China (71501037), and Ciwei Dong's research is partially supported by the National Science Foundation of China (71601187).

Author Contributions: All four authors contributed to the development and completion of this special issue.

Conflicts of Interest: The authors declare no conflict of interest.

\section{References}

1. Boström, M.; Micheletti, M. Introducing the sustainability challenge of textiles and clothing. J. Consum. Policy 2016, 39, 367-375. [CrossRef]

2. Shen, B.; Zheng, J.H.; Chow, P.S.; Chow, K.Y. Perception of fashion sustainability in online community. J. Text. Inst. 2014, 105, 971-979. [CrossRef]

3. Perry, P.; Towers, N. Conceptual framework development: CSR implementation in fashion supply chains. Int. J. Phys. Distrib. Logist. Manag. 2013, 43, 478-500. [CrossRef]

4. Allwood, J.M.; Laursen, S.E.; Russell, S.N.; de Rodriguez, C.M.; Bocken, N.M.P. An approach to scenario analysis of the sustainability of an industrial sector applied to clothing and textiles in the UK. J. Clean. Prod. 2008, 16, 1234-1246. [CrossRef]

5. Shen, B.; Wang, Y.L.; Lo, K.Y.; Shum, M. The impact of ethical fashion on consumer purchase behavior. J. Fash. Mark. Manag. 2012, 16, 234-245. [CrossRef]

6. Shen, B.; Choi, T.M.; Wang, Y.L.; Lo, K.Y. The coordination of fashion supply chains with a risk-averse supplier under markdown money policy. IEEE Trans. Syst. Man Cybern. Syst. 2013, 43, 266-276. [CrossRef]

7. Shen, B. Sustainable fashion supply chain: Lessons from H\&M. Sustainability 2014, 6, 6239-6249.

8. Wang, L.; Shen, B. A product line analysis for eco-designed fashion products: Evidence from an outdoor sportswear brand. Sustainability 2017, 9, 1136. [CrossRef]

9. Shen, B.; Li, Q.Y. Impacts of returning unsold products in retail outsourcing fashion supply chain: A sustainability analysis. Sustainability 2015, 7, 1172-1185. [CrossRef]

10. Dong, C.W.; Shen, B.; Chow, P.S.; Yang, L.; Ng, C.T. Sustainability investment under cap-and-trade regulation. Ann. Oper. Res. 2016, 240, 509-531. [CrossRef]

11. Shen, B.; Choi, T.M.; Lo, K.Y. Enhancing economic sustainability by markdown money supply contracts in the fashion industry: China vs. U.S.A. Sustainability 2016, 8, 31. [CrossRef]

12. Li, Q.; Shen, B. Sustainable design operations in the supply chain: Non-profit manufacturer vs. for-profit manufacturer. Sustainability 2016, 8, 639. [CrossRef]

13. Shen, B.; Ding, X.M.; Chen, L.Z.; Chan, H.L. Low carbon supply chain with energy consumption constraints: Case studies from China's textile industry and simple analytical model. Supply Chain Manag. Int. J. 2017, 22, 258-269. [CrossRef]

14. De Brito, M.P.; Carbone, V.; Blanquart, C.M. Towards a sustainable fashion retail supply chain in Europe: Organisation and performance. Int. J. Prod. Econ. 2008, 114, 534-553. [CrossRef]

15. Nagurney, A.; Yu, M. Sustainable fashion supply chain management under oligopolistic competition and brand differentiation. Int. J. Prod. Econ. 2012, 135, 532-540. [CrossRef]

16. Ho, H.P.Y.; Choi, T.M. A Five R analysis for sustainable fashion supply chain management in Hong Kong: A case analysis. J. Fash. Mark. Manag. 2012, 16, 161-175.

17. Turker, D.; Altuntas, C. Sustainable supply chain management in the fast fashion industry: An analysis of corporate reports. Eur. Manag. J. 2014, 32, 837-849. [CrossRef]

18. Diabat, A.; Kannan, D.; Mathiyazhagan, K. Analysis of enablers for implementation of sustainable supply chain management-A textile case. J. Clean. Prod. 2014, 83, 391-403. [CrossRef]

19. Choi, T.M.; Chiu, C.H. Mean-downside-risk and mean-variance newsvendor models: Implications for sustainable fashion retailing. Int. J. Prod. Econ. 2012, 135, 552-560. [CrossRef]

20. Köksal, D.; Strähle, J.; Müller, M.; Freise, M. Social sustainable supply chain management in the textile and apparel industry-A literature review. Sustainability 2017, 9, 100. [CrossRef]

21. Yang, S.; Song, Y.; Tong, S. Sustainable retailing in the fashion industry: A systematic literature review. Sustainability 2017, 9, 1266. [CrossRef] 
22. Guo, Z.; Liu, H.; Zhang, D.; Yang, J. Green supplier evaluation and selection in apparel manufacturing using a fuzzy multi-criteria decision-making approach. Sustainability 2017, 9, 650. [CrossRef]

23. Kim, D.; Kim, S. Sustainable supply chain based on news articles and sustainability reports: Text mining with Leximancer and DICTION. Sustainability 2017, 9, 1008. [CrossRef]

24. Lee, S.H.; Ha-Brookshire, J. Ethical climate and job attitude in fashion retail employees' turnover intention, and perceived organizational sustainability performance: A cross-sectional study. Sustainability 2017, 9, 465. [CrossRef]

25. Norum, P.S. Towards sustainable clothing disposition: Exploring the consumer choice to use trash as a disposal option. Sustainability 2017, 9, 1187. [CrossRef]

26. Yang, L.; Dong, S. Sustainable product strategy in apparel industry with consumer behavior consideration. Sustainability 2017, 9, 920. [CrossRef]

27. Li, B.; Wu, K. Environmental Management System adoption and the operational performance of firm in the textile and apparel industry of China. Sustainability 2017, 9, 992. [CrossRef]

28. Le, T.; Wang, C. The integrated approach for sustainable performance evaluation in value chain of Vietnam textile and apparel industry. Sustainability 2017, 9, 477. [CrossRef]

29. Niu, B.; Chen, L.; Zhang, J. Sustainability analysis of supply chains with fashion products under alternative power structures and loss-averse supplier. Sustainability 2017, 9, 995. [CrossRef]

30. Shi, X.; Qian, Y.; Dong, C. Economic and environmental performance of fashion supply chain: The joint effect of power structure and sustainable investment. Sustainability 2017, 9, 961. [CrossRef]

31. LoMonaco-Benzing, R.; Ha-Brookshire, J. Sustainability as social contract: Textile and apparel professionals' value conflicts within the corporate moral responsibility spectrum. Sustainability 2016, 8, 1278. [CrossRef]

32. Yang, Y.; Han, H.; Lee, P.K.C. An exploratory study of the mechanism of sustainable value creation in the luxury fashion industry. Sustainability 2017, 9, 483. [CrossRef]

33. Oelze, N. Sustainable supply chain management implementation-Enablers and barriers in the textile industry. Sustainability 2017, 9, 1435. [CrossRef]

34. Chen, C.; Perry, P.; Yang, Y.; Yang, C. Decent work in the Chinese apparel industry: Comparative analysis of blue-collar and white-collar garment workers. Sustainability 2017, 9, 1344. [CrossRef]

(C) 2017 by the authors. Licensee MDPI, Basel, Switzerland. This article is an open access article distributed under the terms and conditions of the Creative Commons Attribution (CC BY) license (http:/ / creativecommons.org/licenses/by/4.0/). 